\title{
Effects of alpha lipoic acid on intra-abdominal adhesion: an experimental study in a rat model
}

\author{
Tülay Diken Allahverdi, M.D.,, ${ }^{1}$ Ertuğrul Allahverdi, M.D., ${ }^{2}$ Sadık Yayla, M.D., ${ }^{3}$ \\ Turgay Deprem, M.D., ${ }^{4}$ Oguz Merhan, M.D., ${ }^{5}$ Sevil Vural, M.D., ${ }^{6}$ \\ Barlas Sülü, M.D., ${ }^{1}$ Yavuz Günerhan, M.D., ${ }^{3}$ Neşet Köksal, M.D. ${ }^{1}$
}

\begin{abstract}
${ }^{1}$ Department of General Surgery, Kafkas University Faculty of Medicine, Kars;
2Departmant of Orthopedic and Traumatology, Kars State Hospital, Kars;

${ }^{3}$ Department of Surgery, Kafkas University Faculty of Veterinary, Kars;

${ }^{4}$ Department of Histology, Kafkas University Faculty of Veterinary, Kars;

${ }^{5}$ Department of Biochemistry, Kafkas University Faculty of Veterinary, Kars;

${ }^{6}$ Department of Patology, Ankara University Faculty of Veterinary, Ankara
\end{abstract}

\begin{abstract}
BACKGROUND: This study was performed to determine the effect of alpha lipoic acid, a powerful antioxidant, on intra-abdominal adhesion formation.

METHODS: Twenty-four female Wistar Albino rats weighing 250-300 g were used in this study conducted on three groups consisting of the alpha lipoic acid group (Group I, n=8), control group (Group II, n=8), and sham group (Group III, n=8). After performing laparotomy with a midline incision under general anesthesia, the adhesion model was created on the antimesenteric side of the caecum in Group I and Group II. $50 \mathrm{mg} / \mathrm{kg}$ alpha-lipoic acid was administered intraperitoneally (IP) in Group I while the surgical procedure was performed but no drugs administered in Group II. Only laparotomy was performed in Group III. Rats were sacrificed at the end of the tenth day.
\end{abstract}

RESULTS: Macroscopic scoring was performed, tissue samples were obtained and subjected to biochemical and histopathological evaluation. The degree of adhesion and malondialdehyde level decreased $(p<0.0 \mathrm{I})$, and glutathione levels had increased $(p<0.0 \mathrm{I})$ in Group I compared to Group II in macroscopic scoring.

CONCLUSION: Alpha lipoic acid was found to significantly decrease $(p<0.0 \mathrm{I})$ intra-abdominal adhesion when administered IP compared to the control group.

Key words: Alpha lipoic acid; peritoneal adhesion; rat.

\section{INTRODUCTION}

Adhesion formation is frequently encountered after trauma or surgical procedures. ${ }^{[1-3]}$ Postoperative intra-abdominal adhesion rates of $60-95 \%$ have been noted. ${ }^{[3]}$ Postoperative adhesions can cause complications such as small bowel obstruction, chronic pelvic pain, and infertility that may affect an individual's quality of life. ${ }^{[2-5]}$

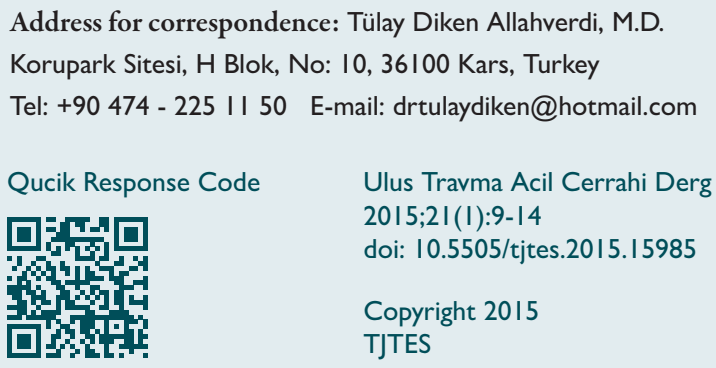

Although the use of barrier forming agents, such as fibrinolytic agents, anticoagulants, anti-inflammatory agents, antibiotics, surfactants, and seprafilm, are emphasized to prevent intra-abdominal adhesions, there is no totally effective method or substance. The issue, therefore, remains current and studies continue. ${ }^{[6-9]}$

The alpha-lipoic acid molecule is oxidized and converted to dihydrolipoic acid (DHLA) during the first contact of alphalipoic acid (ALA), an antioxidant substance, with free radicals. [10-13] Alpha lipoic acid also has anti-inflammatory effects and increases the levels of glutathione (GSH), tocopherol, and other natural antioxidants as ascorbic acid. It can indirectly affect the continuity of the cellular antioxidant defense. ${ }^{[10]}$ Due to its strong antioxidant nature, ALA has been reported to have positive effects in various pathological conditions such as diabetes, arteriosclerosis, neuron degeneration, multiple sclerosis, and joint diseases. ${ }^{[10,13]}$ Özler et al. ${ }^{[1]}$ have reported that oral ALA reduces oxidative stress and has beneficial ef- 
fects in intra-abdominal adhesion formation. However, we did not come across any other study using the oral form to prevent intra-abdominal adhesions.

Nonsteroidal anti-inflammatories and antioxidants have been reported to reduce intra-abdominal adhesion formation. . $^{[1,2,67]}$ Similar results have been reported with oral ALA having an antioxidant effectl. Our aim in this study was to investigate the effect of ALA on adhesion formation when administered intraperitoneally in an experimental rat model.

\section{MATERIALS AND METHODS}

This study was conducted with the permission of the Local Ethics Committee for Animal Experiments of Kafkas University (KAÜ-HADYEK - 20I2-3I).

\section{Animals}

A total of twenty-four Wistar albino female rats with a live weight of 250-300 g were used with eight animals each in three groups.

Group I: Alpha lipoic acid (ALA) group (the group with the adhesion model where $50 \mathrm{mg} / \mathrm{kg}$ alpha lipoic acid was administered intraperitoneally),

Group II: Control group (the group where only the adhesion model was created),

Group III: Sham group (the group where only laparotomy was performed).

\section{Surgical Procedure}

Rats, in all study groups, were kept in the laboratory environment for a week before the experiment and were fed ad libitum with standard rat chow and water. The rats were anesthetized using intraperitoneal $10 \mathrm{mg} / \mathrm{kg}$ xylazine $\mathrm{HCl}$ (Rompun \%2, Bayer - Turkey) and $80 \mathrm{mg} / \mathrm{kg}$ ketamin $\mathrm{HCl}$ (Ketasol, $50 \mathrm{mg} / \mathrm{ml}$, inj., İnterhas, Türkiye) combination. The animals were placed on the operation table in supine position and the ventral abdominal area was prepared for aseptic surgery. A $3 \mathrm{~cm}$ midline incision was made. The cecum was revealed in Groups I and II and after its anterior wall was determined, it was rubbed with a gauze pad held with a clamp until serous punctate hemorrhages were created (Fig. I). The parietal peritoneum was then held with a clamp I cm right lateral to the incision and was sutured with $3 / 0$ polyglactin 910 (Vicryl, Dogssan, Trabzon-Turkey). The abdomen was closed properly after $50 \mathrm{mg} / \mathrm{kg}$ alpha lipoic acid (Thioctazid purchased from Sigma-Aldrich Chemical Co., St. Louis, MO, USA) was administered intraperitoneally in Group I and with no drug administration in Group II. Only laparotomy with a midline incision was performed in Group III (Sham group). After completion of all transactions in each group, the operation site was closed properly and the animals were put in

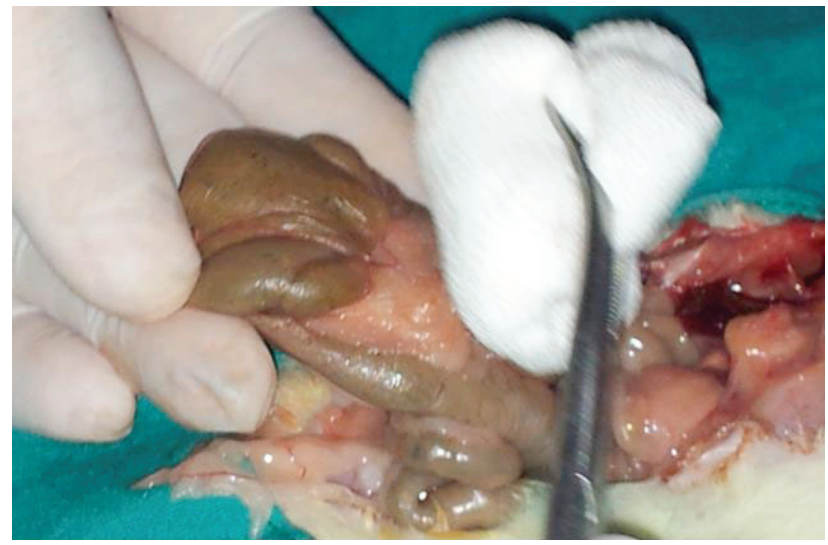

Figure 1. Model of adhesion.

individual cages to be monitored. Second generation cephalosporin was administered to the gluteal muscle for a total of three pre and post-operative days.

\section{Macroscopic Evaluation}

The rats were sacrificed by cervical dislocation under general anesthesia on the tenth day. $A \cup$ incision was performed on the abdomen and the abdominal wall was retracted to provide maximum exposure. Adhesions were quantitatively evaluated blindly by two specialists and scored using the classification described in the literature. ${ }^{[14,15]}$

Grade 0: No adhesion.

Grade I: A single adhesive band between the organs or between the organ and abdominal wall.

Grade 2: Two adhesive bands between the organs or between the organ and abdominal wall.

Grade 3: More than two adhesive bands between the organs or between the organ and abdominal wall or adhesions of intestinal organs with or without adhesions to the abdominal wall.

Grade 4: Viscera directly attached to the abdominal wall.

\section{Biochemical Evaluation}

Tissue samples were obtained for malondialdehyde (MDA) and glutathione peroxidase (GSH) measurements from the area in the caecum where the suture was placed and these were measured spectrophotometrically (UV-I20I, Shimadzu, Japan) according to the method reported by Beutler et al. ${ }^{[16]}$ and Yoshioka et al. ${ }^{[17]}$

\section{Histopathologic Evaluation}

The adhesive band was resected together with the affected organs in rats with adhesion while the anterior cecum was resected with the parietal peritoneum in rats without adhesion and evaluated histopathologically. For this purpose, the 5-micron-thick sections obtained from paraffin blocks were 

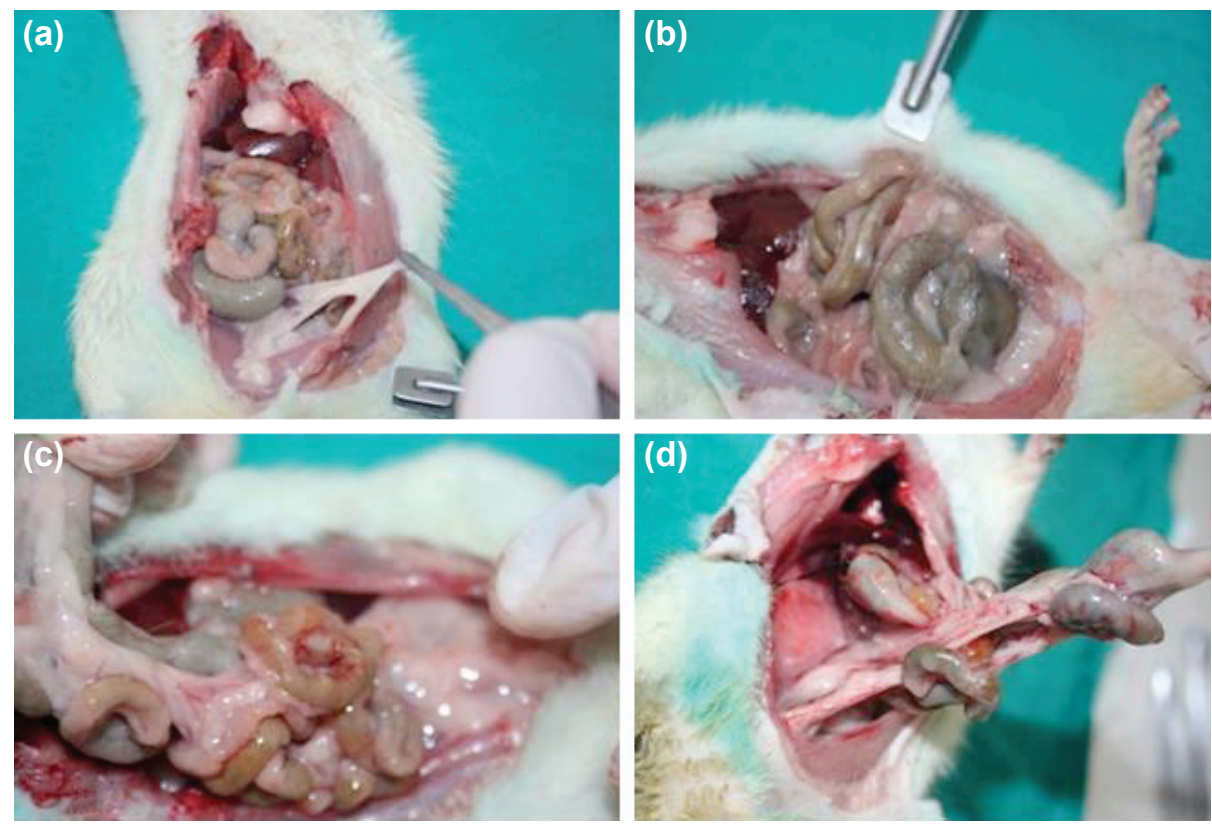

Figure 2. Macroscopic score findings, (a) Grade 1, (b) Grade 2, (c) Grade 3, (d) Grade 4.

stained with hematoxylin-eosin $(\mathrm{H} \& \mathrm{E})$, evaluated under a light microscope (Leica DM4000B) and recorded (Leica DFC280). The grading of lesions was performed based on inflammatory and necrotic changes according to the scoring system below in ten different fields at the same magnification (H\&ExI00).

(-) No lesion was found

$(+) \quad$ Mild lesions (<10\%)

$(++)$ Moderate lesions (10-50\%)

$(+++)$ Severe lesions $(<50 \%)$

\section{Statistics}

SPSS 8 software package was used for the statistical analysis of all data obtained from the study. Mean and standard de- viations and the central distribution criteria were calculated for statistical analysis and the differences between nominal values of the groups were evaluated with Fisher's definite chisquare test for the analysis of nonparametric data. $P$ values $<0.05$ were considered significant. The significance between the two groups for parameters found to be statistically significant in the Kruskall-Wallis test was evaluated with the Mann-Whitney $U$ test and $P$ values $<0.015$ after Bonferroni correction were considered significant.

\section{RESULTS}

One animal each in Groups I and III and two animals in Group II died in the postoperative period and were not included into the evaluation.

Table I. Macroscopic adhesion, biochemical and histopathological findings by group

\begin{tabular}{lccc}
\hline Parameters & $\begin{array}{c}\text { Group I } \\
(\mathbf{n}=7)\end{array}$ & $\begin{array}{c}\text { Group II } \\
(\mathbf{n}=6)\end{array}$ & $\begin{array}{c}\text { Group III } \\
(\mathbf{n}=7)\end{array}$ \\
\hline Macroscopic adhesion & $11.50^{\mathrm{a}}$ & $16.75^{\mathrm{b}}$ & $4.14^{\mathrm{c}}$ \\
$\begin{array}{l}\text { Biochemical results } \\
\text { MDA }\end{array}$ & $11.50^{\mathrm{a}}$ & $16.92^{\mathrm{b}}$ & $4.00^{\mathrm{c}}$ \\
GSH & $16.93^{\mathrm{a}}$ & $4.75^{\mathrm{b}}$ & $9.00^{\mathrm{c}}$ \\
Histopathological findings & $12.14^{\mathrm{ab}}$ & & \\
Edema and hyperemia & $6.93^{\mathrm{a}}$ & $13.33^{\mathrm{a}}$ & $6.43^{\mathrm{b}}$ \\
Inflammatory cell infiltration & $12.71^{\mathrm{ab}}$ & $16.00^{\mathrm{a}}$ & $9.36^{\mathrm{b}}$ \\
Fibrosis & $7.50^{\mathrm{a}}$ & $13.17^{\mathrm{a}}$ & $6.00^{\mathrm{b}}$ \\
Adhesion & $11.00^{\mathrm{a}}$ & $17.50^{\mathrm{b}}$ & $7.50^{\mathrm{a}}$ \\
Necrosis & $11.08^{\mathrm{a}}$ & $9.50^{\mathrm{a}}$ \\
\hline a-c: Different letters on the same line show a statistically significant difference $(\mathrm{p}<0.05)$. &
\end{tabular}




\section{Macroscopic Evaluation}

All animals underwent relaparotomy to expose the abdominal cavity and evaluation was performed according to the NAIR scoring system (Fig. 2 a-d). A statistically significant lower value was found in Group I than in Group II $(p<0.05)$ (Table I).

\section{Biochemical Results}

A significant difference was found between the groups in terms of MDA and GSH ( $p<0.05)$. A significant decrease was found in Group I compared to Group II in terms of MDA $(p<0.05)$. GSH was higher in Group I compared to both Groups II and III.

\section{Histopathological Evaluation}

Group I: The vessels were hyperemic in all cases. Lymphocytepredominant mononuclear cell infiltration and edematous changes were noticed in three cases (ALAI, 3, 6). Mononuclear cell infiltrations with sporadic mast cell and neutrophil leukocytes (ALA4, 5) mostly consisting of lymphocytes (Fig. $3 a$ ), edema and capillarization were found in the submucosa, especially around the vessels; mononuclear cells were also noticed in the tunica muscularis. Two cases had foreign body granulation tissue with fibrosis and edema due to thickening in the tunica serosa.

One case (ALA) had marked necrosis in the lamina propria and degenerative changes and clusters of bacteria in the muscles.

Group II: We noticed wide necrosis areas starting from the lumen section of the lamina epithelialis to the tunica muscularis together with solid or necrotic neutrophilic leukocyte infiltration (Fig. 3b), edematous changes, hyperemia and capillarization in one of the six cases in the control group. Thickening due to fibrosis was observed in this layer in four patients. Mononuclear cell infiltration was encountered in the lamina propria, tunica muscularis, and tunica serosa.

Group III: Lesions in the sham group were generally limited to the lamina propria and submucosa. Mononuclear cell infiltration was evident in both layers. These cells were accompanied by a small number of neutrophilic leukocytes in the lamina propria in one case and a granuloma in the submucosa in another (Fig. $3 \mathrm{c}$ ). There were edematous changes in some places.

\section{DISCUSSION}

Intra-abdominal adhesions that are likely to develop after trauma or surgery have an important place in practicel,2. Laparoscopic procedures are preferred to open surgery with the aim of reducing peritoneal trauma to prevent adhesions. ${ }^{[1-3]}$ Pharmacological agents preventing fibrin formation such as tissue plasminogen activator and heparin, and barrier products such as seprafilm are also available, ${ }^{[1,2,8]}$ although none
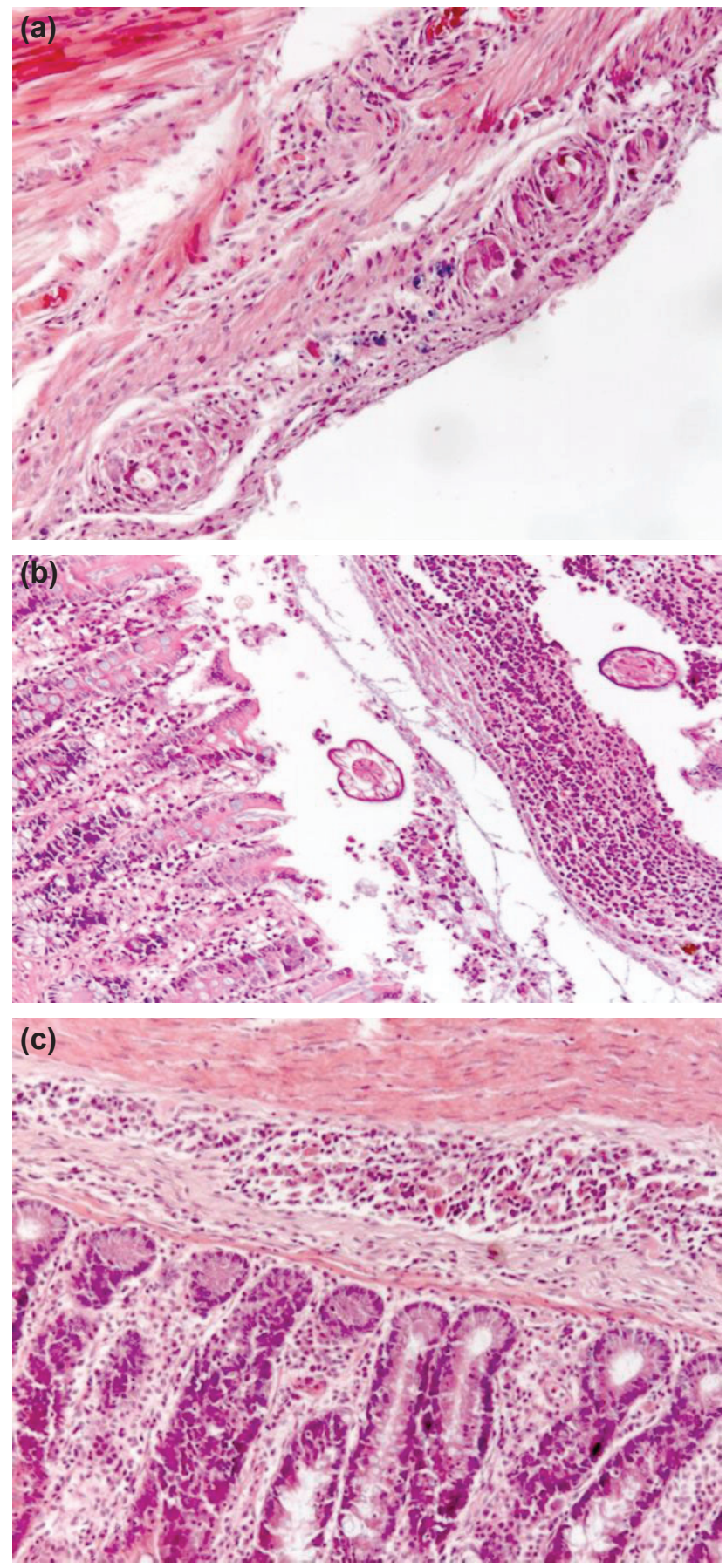

Figure 3. (a) Reduce of neutrophil leukocytes infiltration and edematous changes in the submucosa, H\&Ex100. (b) Necrotic neutrophilic leukocyte infiltration, edematous changes, hyperemia and capillarization, H\&Ex100. (c) Neutrophilic leukocyte infiltration in the lamina propria and a granuloma in the submucosa, H\&Ex100.

of them can completely prevent intra-abdominal adhesion. Recent studies have shown increased oxidative stress during peritoneal recovery and a positive relationship between oxidative stress and adhesion severity. Peritoneal adhesion formation was reported to decrease with the use of an antioxidant substance. ${ }^{[1,2]}$ Our aim in this study was to investigate the effects of intraperitoneal administration of ALA, which 
has an antioxidant effect, on intra-abdominal adhesion formation.

The powerful biological antioxidant ALA can be used orally or intraperitoneally. ${ }^{[1,10]}$ Özler et al. ${ }^{[1]}$ have reported that ALA decreases adhesion when administered orally at a dose of 100 $\mathrm{mg} / \mathrm{kg}$. Ozbal et al. ${ }^{\left[{ }^{10]}\right.}$ have also stated high dose as a single intraperitoneal dose of $100 \mathrm{mg} / \mathrm{kg}$. Testicular ischemia and reperfusion injury have been reduced by ALA as well in that study. Our aim was to determine whether ALA, given at high doses in the other two studies and shown to have anti-inflammatory and antioxidant effects, had any effect on adhesion when administered at a lower dose $(50 \mathrm{mg} / \mathrm{kg})$. Drugs have side effects in addition to therapeutic effects therefore the lowest therapeutic dose should be administered to decrease the incidence of side effects. ALA reaches its peak concentration thirty minutes to two hours after administration and is rapidly metabolized. Since inflammation starts in minutes after surgical trauma, the drug should reach an effective concentration at the moment of injury. ${ }^{[18,19]}$ ALA was administered intraoperatively in our study.

Alleva et al. have shown with various parameters that ALA has positive effects on wound healing. ${ }^{[20]}$ Lipoic acid has also been shown to regulate angiogenesis in many studies, ${ }^{[2]} \mathrm{de}-$ creasing adhesion formation. Özler et al. have evaluated macroscopic adhesion with alpha lipoic acid by administering the drug in oral form and found adhesion to be decreased. Macroscopic adhesion evaluation of our study showed that the IP use of ALA significantly decreased adhesion compared to the control group. It is to our belief that ALA continues to exert positive effects when administered through the IP route.

MDA level indicates the presence of lipid peroxidation due to free oxygen radicals produced in tissues after ischemia and has been shown to increase after peritoneal adhesion and decrease with antioxidant use. ${ }^{[1,2]}$ MDA level was found to show a significant decrease in the group administered with ALA compared to the control group in our study. This decrease had a course close to the sham group.

When ischemic damage occurs, glutathione is consumed through conjugation and the intracellular glutathione level is consequently reduced. The decrease in the amount of glutathione is compensated by exogenous GSH intake. When oxidative stress increases, a decrease in glutathione occurs. When oxidative stress decreases, an increase is observed in the glutathione level. ${ }^{[22]}$ ALA has been shown to increase glutathione levels and decrease cell death in a study conducted by Rocamonde et al. ${ }^{[21]}$ A significant increase in the GSH level was found in the group where antioxidant was administered compared to the control group. This increase was close to the level of the sham group. The increase of MDA level and decrease of GSH level in the group where ALA was administered is one more indicator that ALA is a powerful antioxidant.
Lin et al. ${ }^{[13]}$ have reported a decrease in edema and hyperemia, inflammation, fibrosis and alveolar wall thickness in acute lung trauma with the use of ALA. The author links this effect of ALA to the decreased release of the proinflammatory cytokines and its anti-inflammatory effect. A significant decrease was seen in edema and hyperemia, inflammation, fibrosis and adhesion in the drug-treated group compared to the control group in the microscopic evaluation of our study. However, no significant difference was seen in the necrosis rate between the groups. As Lin et al. ${ }^{[13]}$ has stated, it is possible to link the significant decrease in all microscopic vales evaluated to a reduction in the secretion of cytokines and anti-inflammatory effect of ALA.

ALA, a naturally occurring thiol antioxidant, is used to prevent hepatic fibrosis in clinical practice and can also be used to prevent submucous fibrosis and peritoneal adhesion with oral use. ${ }^{[23]}$ Low doses of intraperitoneal ALA was found to prevent intraabdominal adhesion due to the effects similar to those reported in the literature, ${ }^{[10-13]}$ indicating the lack of a difference between low and high doses in terms of decreasing adhesion. Determining the lowest dose of ALA that is effective in preventing intraabdominal adhesions requires further studies.

\section{Conflict of interest: None declared.}

\section{REFERENCES}

1. Özler M, Ersöz N, Özerhan İH, Topal T, Öter Ş, Korkmaz A. The effect of alpha-lipoic acid in the prevention of peritoneal adhesions. Turk J Gastroenterol 2011;22:190-4.

2. Celeplı S, Kismet K, Kaptanoğlu B, Erel S, Ozer S, Celeplı P, et al. The effect of oral honey and pollen on postoperative intraabdominal adhesions. Turk J Gastroenterol 2011;22:65-72.

3. Kirdak T, Uysal E, Korun N. Assessment of effectiveness of different doses of methylprednisolone on intraabdominal adhesion prevention. Ulus Travma Acil Cerrahi Derg 2008;14:188-91.

4. Müller SA, Treutner KH, Tietze L, Anurov M, Titkova S, Polivoda M, et al. Efficacy of adhesion prevention and impact on wound healing of intraperitoneal phospholipids. J Surg Res 2001;96:68-74. CrossRef

5. Saed GM, Munkarah AR, Diamond MP. Cyclooxygenase-2 is expressed in human fibroblasts isolated from intraperitoneal adhesions but not from normal peritoneal tissues. Fertil Steril 2003;79:1404-8. CrossRef

6. Guvenal T, Cetin A, Ozdemir H, Yanar O, Kaya T. Prevention of postoperative adhesion formation in rat uterine horn model by nimesulide: a selective COX-2 inhibitor. Hum Reprod 2001;16:1732-5. CrossRef

7. Cofer KF, Himebaugh KS, Gauvin JM, Hurd WW. Inhibition of adhesion reformation in the rabbit model by meclofenamate: an inhibitor of both prostaglandin and leukotriene production. Fertil Steril 1994;62:1262-5.

8. Inoue M, Uchida K, Otake K, Nagano Y, Ide S, Hashimoto K, et al. Efficacy of Seprafilm for preventing adhesive bowel obstruction and costbenefit analysis in pediatric patients undergoing laparotomy. J Pediatr Surg 2013;48:1528-34. CrossRef

9. Golan A, Maymon R, Winograd I, Bukovsky I. Prevention of post-surgical adhesion formation using aspirin in a rodent model: a preliminary report. Hum Reprod 1995;10:1797-800. 
10. Ozbal S, Ergur BU, Erbil G, Tekmen I, Bagriyanı A, Cavdar Z. The effects of $\alpha$-lipoic acid against testicular ischemia-reperfusion injury in Rats. ScientificWorldJournal 2012;2012:489248. CrossRef

11. Moini H, Packer L, Saris NE. Antioxidant and prooxidant activities of alpha-lipoic acid and dihydrolipoic acid. Toxicol Appl Pharmacol 2002;182:84-90. CrossRef

12. Kiemer AK, Müller C, Vollmar AM. Inhibition of LPS-induced nitric oxide and TNF-alpha production by alpha-lipoic acid in rat Kupffer cells and in RAW 264.7 murine macrophages. Immunol Cell Biol 2002;80:550-7. CrossRef

13. Lin YC, Lai YS, Chou TC. The protective effect of alpha-lipoic Acid in lipopolysaccharide-induced acute lung injury is mediated by heme oxygenase-1. Evid Based Complement Alternat Med 2013;2013:590363.

14. Galili Y, Ben-Abraham R, Rabau M, Klausner J, Kluger Y. Reduction of surgery-induced peritoneal adhesions by methylene blue. Am J Surg 1998;175:30-2. CrossRef

15. Hemadeh O, Chilukuri S, Bonet V, Hussein S, Chaudry IH. Prevention of peritoneal adhesions by administration of sodium carboxymethyl cellulose and oral vitamin E. Surgery 1993;114:907-10.

16. Beutler E, Duron O, Kelly BM. Improved method for the determination of blood glutathione. J Lab Clin Med 1963;61:882-8.

17. Yoshioka T, Kawada K, Shimada T, Mori M. Lipid peroxidation in ma- ternal and cord blood and protective mechanism against activated-oxygen toxicity in the blood. Am J Obstet Gynecol 1979;135:372-6.

18. Liebman SM, Langer JC, Marshall JS, Collins SM. Role of mast cells in peritoneal adhesion formation. Am J Surg 1993;165:127-30. CrossRef

19. Siegler AM, Kontopoulos V, Wang CF. Prevention of postoperative adhesions in rabbits with ibuprofen, a nonsteroidal anti-inflammatory agent. Fertil Steril 1980;34:46-9.

20. Alleva R, Tomasetti M, Sartini D, Emanuelli M, Nasole E, Di Donato F, et al. alpha-Lipoic acid modulates extracellular matrix and angiogenesis gene expression in non-healing wounds treated with hyperbaric oxygen therapy. Mol Med 2008;14:175-83. CrossRef

21. Rocamonde B, Paradells S, Barcia JM, Barcia C, García Verdugo JM, Miranda $\mathrm{M}$, et al. Neuroprotection of lipoic acid treatment promotes angiogenesis and reduces the glial scar formation after brain injury. Neuroscience 2012;224:102-15. CrossRef

22. Jaeschke H. Molecular mechanisms of hepatic ischemia-reperfusion injury and preconditioning. Am J Physiol Gastrointest Liver Physiol 2003;284:G15-26.

23. Kaya M, Yildirim $\mathrm{CH}$, Kosemehmetoglu K, Huseyinoglu U, Erdogan $\mathrm{H}$, Akbasak A, et al. Alpha-lipoic acid reduces peridural fibrosis after laminectomy of lumbar vertebrae in rabbits. Acta Neurochir (Wien) 2012;154:1241-5. CrossRef

\title{
DENEYSEL ÇALIŞMA - ÖZET
}

\section{Alfa lipoik asitin intraabdominal adezyon üzerine etkileri: Sıçan modelinde deneysel bir çalışma \\ Dr. Tülay Diken Allahverdi, ${ }^{1}$ Dr. Ertuğrul Allahverdi, ${ }^{2}$ Dr. Sadık Yayla, ${ }^{3}$ Dr. Turgay Deprem, ${ }^{4}$ \\ Dr. Oguz Merhan, ${ }^{5}$ Dr. Sevil Vural, ${ }^{6}$ Dr. Barlas Sülü, ${ }^{1}$ Dr. Yavuz Günerhan, ${ }^{3}$ Dr. Neşet Köksal ${ }^{1}$}

\author{
${ }^{1}$ Kafkas Üniversitesi Tıp Fakültesi, Genel Cerrahi Anabilim Dalı, Kars; \\ ${ }^{2}$ Kars Devlet Hastanesi, Ortopedi ve Travmatoloji Kliniği, Kars; \\ ${ }^{3}$ Kafkas Üniversitesi Veteriner Fakültesi, Cerrahi Anabilim Dalı, Kars; \\ ${ }^{4}$ Kafkas Üniversitesi Veteriner Fakültesi, Histoloji Anabilim Dalı, Kars; \\ ${ }^{5}$ Kafkas Üniversitesi Veteriner Fakültesi, Biyokimya Anabilim Dalı, Kars; \\ ${ }^{6}$ Ankara Üniversitesi Veteriner Fakültesi, Patoloji Anabilim Dalı, Ankara
}

AMAÇ: Çalışma, güçlü bir antioksidan olan alfa lipoik asidin intraabdominal adezyon oluşumu üzerine olan etkisini saptamak amacıyla yapıldı.

GEREÇ VE YÖNTEM: Alfa lipoik asit grubu (Grup I), kontrol grubu (Grup II, n=8) ve Sham grubu (Grup III, n=8) olmak üzere üç grup üzerinde yürütülen bu çalışmada 250-300 g canlı ağırlığında olan Wistar Albino cinsi 24 adet dişi sıçan kullanıldı. Genel anestezisi eşliğinde orta hat insizyonuyla laparotomi yapıldıktan sonra Grup I ve Grup Il'de çekumun antimezenterik tarafında adezyon modeli oluşturuldu. Grup l'e 50 mg/kg alfa lipoik asid intraperitoneal (IP) olarak verilirken Grup II'de cerrahi işlem yapıldı fakat herhangi bir ilaç uygulanmadı. Grup III'te ise sadece laparatomi yapıldı. Sıçanlar 10. gün sonunda sakrifiye edilip makroskopik skorlama yapıldı ve doku örnekleri alınarak biyokimyasal ve histopatolojik değerlendirmeye tabi tutuldu.

BULGULAR: Makroskopik skorlamada ve histopatolojik incelemede Grup l'de, Grup Il'ye göre adezyon derecesinin ve malondialdehid düzeyinin azaldığı $(p<0.0$ I), glutation düzeyinin ise arttı̆̆ $(p<0.0$ I) tespit edildi.

TARTIŞMA: Çalışma bulguları, alfa lipoik asidin IP olarak uygulandığında intraabdominal adezyonu kontrol grubuna göre belirgin derecede azalttı̆̆ı $(p<0.0$ I) tespit edildi.

Anahtar sözcükler: Alfa lipoik asid; peritoneal adezyon; sıçan.

Ulus Travma Acil Cerrahi Derg 2015;2I(I):9-14 doi: 10.5505/tjtes.2015.15985 